\title{
Sublethal responses to endrin in sediment by Stylodrilus heringianus (Lumbriculidae) as measured by a ${ }^{137}$ cesium marker layer technique
}

\author{
Timothy J. Keilty ${ }^{\mathrm{a}}$, David S. White ${ }^{\mathrm{b}}$ and Peter F. Landrum ${ }^{\mathrm{a}}$ \\ ${ }^{a}$ National Oceanic and Atmospheric Administration, Great Lakes Environmental Research \\ Laboratory, Ann Arbor, MI and ${ }^{b}$ Great Lakes Research Division and School of Natural Resources, \\ University of Michigan, Ann Arbor, MI, U.S.A.
}

(Received 12 January 1988; revision received and accepted 25 April 1988)

\begin{abstract}
Sediment reworking rates of Stylodrilus heringianus (Oligochaeta: Lumbriculidae) were measured in microcosms containing sediments dosed with the chlorinated pesticide, endrin. Reworking rates were measured at $10^{\circ} \mathrm{C}$ by monitoring a ${ }^{137}$ cesium marker layer burial in contaminated and uncontaminated microcosms. Endrin concentrations ranged from 3.1 to $42000 \mathrm{ng} / \mathrm{g}$ dry sediment. Alterations in reworking rates were observed at sediment concentrations five and one half orders of magnitude below the $\mathbf{L C}_{50}$ $(1650 \mu \mathrm{g} / \mathrm{g})$. For the lower concentrations, marker layer burial rate data suggested possible stimulatory effects in the first 300 to $600 \mathrm{~h}$, followed by significant rate decreases relative to controls. For higher concentrations, rates were equal to or slower than control rates in the first $600 \mathrm{~h}$, followed by dramatic decreases in the last $600 \mathrm{~h}$. High final surficial sediment endrin concentrations at the end of experiments implied worm mediated upward transport. Worm mortalities were 9.3 to $28 \%$ for the two highest concentrations (42000 and $11500 \mathrm{ng} / \mathrm{g}$ ) and 0 to $6.7 \%$ for all other concentrations including controls. Post experimental worm dry weights were inversely related to high concentrations. Bioaccumulation factors ranged from 34 to 67 on a $\mathrm{g}$ dry organism to $\mathrm{g}$ dry sediment basis.
\end{abstract}

Key words: Sediment toxicity; Oligochaete; Biogenic sediment mixing; Bioturbation

\section{INTRODUCTION}

Toxic compounds with high partition coefficients that enter the Laurentian Great Lakes adsorb significantly to fine particles and settle to the bottom. The fate of these compounds and their interactions with macrobenthic organisms is largely unknown. Compound fates depend on complex combinations of sediment characteristics, xenobiotic chemical and physical properties, and the activity patterns of the benthos

Correspondence to: T.J. Keilty, National Oceanic and Atmospheric Administration, Great Lakes Environmental Research Laboratory, 2205 Commonwealth Blvd., Ann Arbor, MI 48105, U.S.A. 
(Petr, 1977). Sediment mixing is directly related to the latter (Robbins, 1982), and of particular interest are the oligochaetes that rework sediments in a conveyor-belt fashion (Davis, 1974a; Rhoads, 1974; Robbins and Edgington, 1975; Krezoski, 1976; Robbins et al., 1977; Krezoski et al., 1978; Robbins et al., 1979; McCall and Fisher, 1980; Krezoski, 1981; Robbins, 1982; Robbins et al., 1984; Krezoski and Robbins, 1985; Robbins, 1986). Worms ingest subsurface sediments and convey them to the sediment-water interface, egesting the sediment particles as fecal pellets. The continuance of this feeding behavior (and other related modes such as funnelfeeding by marine polychaetes) affects stratigraphic records and physical-chemical properties of bottom sediments (Kikuchi and Kurihara, 1966; McCall and Tavesz, 1982). Radionuclide and pollen grain distributions from lake bottom cores and laboratory microcosm studies reflect a zone of uniform mixing of surface sediments to depths that correlate with oligochaete abundance and feeding patterns (Davis, 1974a; Robbins and Edgington, 1975; Edgington and Robbins, 1976; Fisher et al., 1980; Robbins et al., 1988). Similar observations of marine polychaetes have also been reported (Cadee, 1979; Baumfalk, 1979). Additionally, the effects of aquatic worms on sediment diagenesis and transport of materials across the sediment-water interface have been demonstrated (Davis, 1974b; Davis et al., 1975; Petr, 1977; Aller, 1978; Aller, 1980; Aller, 1982; Rippey and Jewsen, 1982; Fisher, 1982; Krezoski et al., 1984; Matisoff et al., 1985; Karickoff and Morris, 1985).

Rates at which buried sediments are egested and subsequently reburied (the reworking rate) have been determined under laboratory conditions for Stylodrilus heringianus (Krezoski, 1981; Robbins et al., 1984) and for mixed tubificid assemblages (predominantly Limnodrilus hoffmeisteri, McCall and Fisher, 1980; Fisher et al., 1980). Only very recently have contaminated sediment-oligochaete (tubificids) interactions been examined under laboratory conditions. Tubificids transported toxicants (hexachlorobenzene, pentachlorobenzene, and trifluralin) to the sediment surface in microcosms. The reworking activities resulting in the toxicant transport were assumed to be independent of the toxicant's presence (Karickoff and Morris, 1985).

The quantification of burial rates is crucial to studies of both contaminated and uncontaminated sediments. Previously, reworking rates were inferred from either fecal pellet evolution or marker horizon (such as fluorescent glass beads, Karickoff and Morris, 1985) studies. In both cases, only gross movements of surface sediments were measured and/or microcosms were destroyed or disrupted during measurement. However, use of the gamma scan method for monitoring laboratory microcosms is both non-destructive and gives high resolution (Robbins et al., 1979). Rate determinations are repeatable and dependent on the conditions imposed upon microcosms (such as oxygen fluctuations, Robbins et al., 1984).

Measurements of sediment reworking reflect the intimate interactions between these sediment-confined organisms and their surroundings. Potential alterations (either increases or decreases) in reworking rates over relatively long periods in con- 
taminated sediments can therefore be compared to reworking rates established in uncontaminated sediments. Such a system is ideal for testing the influences of xenobiotics on conveyor-belt feeding oligochaetes.

In this research, we employ the gamma scan system to determine the existence and magnitude of these alterations in behavior using the chlorinated pesticide endrin as a representative sediment-bound toxicant and the lumbriculid Stylodrilus heringianus as the test organism. We hypothesized that the sediment-bound toxicant should stimulate or depress relative to its concentration the normal reworking/feeding rates of the representative conveyor-belt oligochaete. Additionally, because oligochaete particle selective feeding results in a significant upward redistribution of fine-grained sediments (Robbins, 1986), and toxicants bound to sediments are often associated with the smaller, organic fractions (Karickoff and Morris, 1985), we further hypothesized that oligochaete reworking should result in sediment-bound toxicant redistribution, with potentially high concentrations at or near the sediment-water interface.

\section{MATERIALS AND METHODS}

Two 1300 -h experiments were conducted (experiments 1 and 2). Each tested four sediment endrin concentrations and a control in triplicate. The gamma scan system as described in detail by Robbins et al. (1979) was the primary investigative tool. The system consisted of a well-collimated $\mathrm{NaI}$ scintillation detector supported by a hydraulic elevator. The apparatus was used to vertically scan small microcosms contained in an aquarium modified as an environmental chamber. Before experimental organisms were added to the microcosms, a sub-millimeter layer of the gamma emitting radioisotope ${ }^{137} \mathrm{Cs}$ adsorbed on illite clay particles was added to the sediment surface of each microcosm. A single channel analyzer system was used to isolate counts from the $0.662 \mathrm{MeV}$ energy peak of the ${ }^{137} \mathrm{Cs}$. The top $1.5-3.5 \mathrm{~cm}$ of each microcosm was scanned with the $\mathrm{NaI}$ detector in $\mathrm{mm}$ increments ( $100 \mathrm{~s}$ counts $/ \mathrm{mm}$ ) every 2-5 days after the addition of oligochaetes. Depths of maximum gamma activity were calculated by fitting count data to a Gaussian distribution (Robbins et al., 1979; Krezoski and Robbins, 1985; Robbins, 1986). The hydraulic elevator supporting the lead shielded detector and collimator was mounted on steel casters and angle iron tracks for lateral mobility to permit the scanning of multiple microcosms lined up on the inside wall of the aquariums. Thus, microcosms remained undisturbed for the duration of experiments. When determining the initial location of the peak activity (prior to the addition of the worms), an external mark was made on the track so that the detector could be repeatedly returned to the same location for each cell. After the worms were added, the entire tank was enclosed in black plastic to maintain dark conditions. Microcosm cells $(5.5 \mathrm{~cm} \times 3.5 \mathrm{~cm} \times 30 \mathrm{~cm})$ were constructed of glass (sealed with silicone) to reduce compound adsorption and holding tanks were filled with aerated epilimnetic Lake Michigan water at $10^{\circ} \mathrm{C}$. 
The chlorinated pesticide endrin $(1,2,3,4,10,10$, hexachloro-6,7-epoxy1,4,4a,5,6,7,8,8a-octahydro-1,4-endo, endo-5,8-dimethanonapththalene, molecular weight $=381$, Weil et al., 1974) was chosen as a representative toxicant based on its low chemical solubility in water $\left(0.26 \mathrm{mg} / 1\right.$ at $25^{\circ} \mathrm{C}$, Biggar and Riggs, 1974), acute toxicity in aqueous solution to other aquatic species (reviewed in Grant, 1976), its high partition coefficient ( $\log K_{\text {ow }}=5.6$, Neeley et al., 1974) and its availability in a commercially prepared radiolabelled form (Pathfinder Laboratories, St. Louis, MO).

Sediments and water were collected in Lake Michigan approximately $10 \mathrm{~km}$ offshore from St. Joseph, Michigan, in $42 \mathrm{~m}$ of water. For standardization between experiments, sediments were dried at $60^{\circ} \mathrm{C}$, passed through a $0.25-\mathrm{mm}$ sieve, and reconstituted with lake water as needed. When reconstituting, a few ml of fresh sediment were added to provide an active bacterial flora. For each experimental concentration, endrin $/{ }^{14} \mathrm{C}$ endrin was added to $450 \mathrm{~g}$ dry weight sediment in 21 lake water via an acetone carrier ( $<1 \mathrm{ml}$, also added to controls) and stirred for $24 \mathrm{~h}$ at room temperature. After settling $72 \mathrm{~h}$, overlying water/acetone was aspirated off and fresh lake water added. The new mixture was stirred for approximately $10 \mathrm{~min}$ and then poured equally into each of three microcosms. The slurries were allowed to settle for 10 days at $10^{\circ} \mathrm{C}$. A submillimeter layer of ${ }^{137} \mathrm{Cs}$ adsorbed onto Lake Michigan sediments was then added to the sediment surface of each microcosm. After settling $24 \mathrm{~h}$, each cell was scanned with the detector ( $100 \mathrm{~s}$ counts at $1 \mathrm{~mm}$ intervals for these and all subsequent scannings) to determine the initial position of the peak gamma activity. Seventy five worms were then added to each cell and allowed to burrow for $24 \mathrm{~h}$, after which cells were scanned. Scanning continued every 2-5 days thereafter. Identical set-up and scanning procedures were followed for controls (without endrin).

Worms were collected in March 1984, and April 1985, at the location of sediment collection. They were maintained at $10^{\circ} \mathrm{C}$ in lake sediments in the dark in $200-1$ aquariums for a minimum of one month prior to use. Aquarium sediments were gently sieved $(0.5 \mathrm{~mm})$ to concentrate worms (greater than $25 \mathrm{~mm}$ in length) prior to each experiment. A fiber optic light (to prevent unnecessary heating) and a dissecting microscope were used to identify and count worms within a $48 \mathrm{~h}$ period prior to the start of experiments. To minimize any potential size bias between microcosms, worms were placed in vials of $20 \mathrm{ml}$ aerated lake water in lots of 15 as they were selected. When all needed were obtained, the contents of 5 randomly selected vials were added to each microcosm to correspond to a density of 50000 worm $\mathrm{m}^{-2}$.

At the end of each experiment, two microcosms per treatment were sampled for worm data (percent mortality, dry weight, endrin concentration) and one for a vertical profile of sediment endrin concentration and porosity. Microcosms for vertical profiles were removed from the experimental aquariums and immediately frozen in a dry ice-alcohol bath. By limiting the level of the bath to $2-3 \mathrm{~cm}$ below the sediment surface of a microcosm, distortion effects due to expansion of sediments were 
minimized. To remove the frozen sediment, the silicone seal was cut to remove the bottom of the microcosm. As the outer surface warmed, the entire plug was then pushed free. The plug was wrapped in aluminium foil and cut in centimeter fractions with a fine blade hacksaw. Three 'blank' (no worms, only $\left[{ }^{14} \mathrm{C}\right]$ endrin) microcosms were mixed and treated in the same manner for standards. Porosity was determined by whole fraction wet weight-dry weight/wet weight $\times 100$. Sediments were dried at room temperature and stored in a freezer prior to endrin extractions. Ashfree dry weights were determined on sediments of 'blank' cells to examine the relationship between organic carbon and the distribution of the pesticide. Sediments were ashed in pre-baked and weighed ceramic crucibles at $550^{\circ} \mathrm{C}$ for $4 \mathrm{~h}$.

Post experimental endrin: $\left[{ }^{14} \mathrm{C}\right]$ endrin concentrations were determined by $10 \mathrm{~min}$ liquid scintillation counts using a Packard $460 \mathrm{C}$ counter. Disintegrations per min were calculated for all samples by correcting the measured activities for background and counting efficiency with a standard quench curve. Endrin was removed from the sediment by $8 \mathrm{~h}$ soxhlet extraction in $240 \mathrm{ml}$ hexane and $60 \mathrm{ml}$ acetone after Sharom et al. (1980). Extraction volumes were reduced with a Bulcher flash evaporator to approximately $1 \mathrm{ml}$ before analysis. Liquid scintillation determinations were initially verified with gas chromotography (Varian Aerograph Series 1200, column temp. $210^{\circ} \mathrm{C}$, detector temp. $230^{\circ} \mathrm{C}$ ). GC samples were cleaned up with florisil columns (after Pesticide Analytical Manual, 1979). The radiopurity of the labeled endrin, determined using thin layer chromatography (after Patil et al., 1970), was $>\mathbf{9 8 \%}$. For comparative purposes, distributions of endrin were plotted as the percent of the total microcosm endrin content found at each $\mathrm{cm}$ interval in experimental and 'blank' microcosms.

TABLE I

Percent mortalities of Stylodrilus heringianus from replicate microcosms for experiments 1 and 2.

\begin{tabular}{llcc}
\hline Concentration & \multicolumn{3}{c}{ Percent mortality } \\
\cline { 2 - 4 } & Replicate 1 & Replicate 2 & Mean \\
\hline Experiment 1 & & & \\
$42000 \mathrm{ng} / \mathrm{g}$ & 24.0 & 28.0 & 26.0 \\
$2300 \quad \mathrm{ng} / \mathrm{g}$ & 6.7 & 0.0 & 3.4 \\
$218 \mathrm{ng} / \mathrm{g}$ & 5.3 & 2.7 & 4.0 \\
$20.6 \mathrm{ng} / \mathrm{g}$ & 4.0 & 4.0 & 4.0 \\
Control & 0.0 & $\mathrm{a}$ & 0.0 \\
Experiment 2 & & & \\
$11500 \quad \mathrm{ng} / \mathrm{g}$ & 26.6 & 9.3 & 18.0 \\
$541 \mathrm{ng} / \mathrm{g}$ & 1.3 & 2.7 & 2.0 \\
$27 \mathrm{ng} / \mathrm{g}$ & 0.0 & 1.3 & 0.7 \\
$3.1 \mathrm{ng} / \mathrm{g}$ & 5.3 & 4.0 & 4.7 \\
Control & 2.7 & 6.7 & 4.7 \\
\hline
\end{tabular}

${ }^{a}$ Not assayed (replicate 2 used in determinations of vertical profile variables). 
Whole worm endrin concentrations were obtained by using a Thomas No. 04212 tissue grinder to pulverize dried worms (stored in a dessicator) in acetone. The slurry was centrifuged at $10000 \mathrm{rpm}$ for $10 \mathrm{~min}$. The supernatant was then assayed for ${ }^{14} \mathrm{C}$ activity as above.

Primary statistical analyses included covariance slope comparisons of treatment and control cell ${ }^{137} \mathrm{Cs}$ burial rates (position of the peak activity vs, time) for early and later portions of experiments. All test results were considered significant if $P<0.05$. Analyses of residuals indicated that assumptions of 'normality' and 'equal variances' were not seriously violated (no transformations were used). All computa-
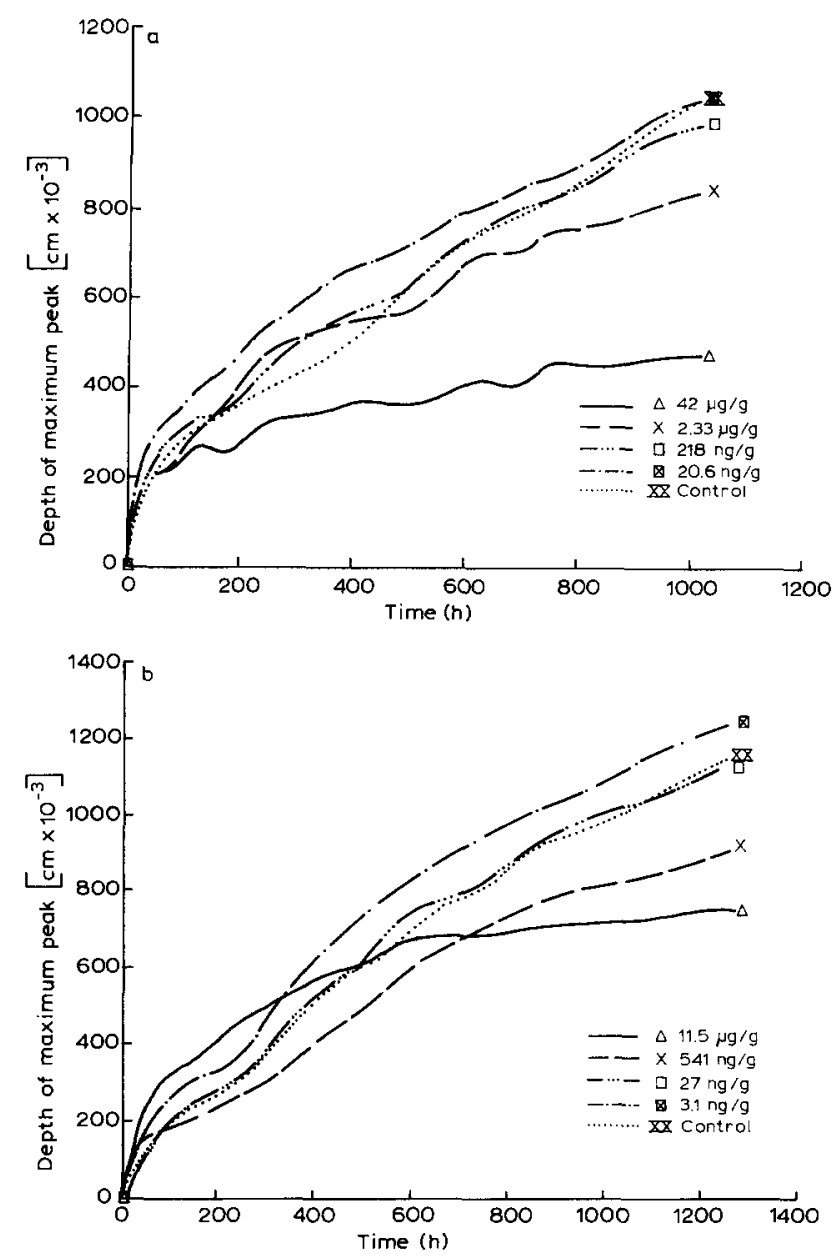

Fig. 1. a,b. Depths of mean $(n=3){ }^{137} \mathrm{Cs}$ peaks as buried by Stylodrilus heringianus in experiments 1 and 2 for experimental sediment endrin concentrations and the control. To avoid cluttering the reworking responses, standard deviations were not plotted. 
tions were made on the Michigan Terminal System using the University of Michigan's statistical package, MIDAS.

\section{RESULTS}

Measured sediment concentrations in the first experiment ranged from 20 to $42000 \mathrm{ng} / \mathrm{g}$ and 3.1 to $11500 \mathrm{ng} / \mathrm{g}$ in the second experiment. In both experiments, mortality was low, although at the two highest concentrations, mortality was significantly higher than other experimental concentrations and controls (Table I). Replicate 2 of the control cells in experiment 1 was eliminated from final analyses due to an apparent mid-experiment catastrophe. At the end of the experiment, the sediment in the microcosm was uncharacteristically black with no life.

Mean deapths of ${ }^{137} \mathrm{Cs}$ peaks were plotted for each experiment to interpret the reworking response (Fig. 1a,b). To describe changes in reworking during the tests, a point where the lines visibly inflected was chosen to divide the data and reworking rates (slope/ 75 worms) were calculated for both the early and later portions (Table II). Slopes were then compared using analyses of covariance (Tables III and IV). All calculations were based on the mean of the responses. Variation among microcosms was low and somewhat constant throughout both experiments. The mean coefficient of variation $(n=5)$ for SD in experiment 1 was $39.0 \pm 15.8$, and $47.4 \pm 13.3$ in experiment 2 .

\section{TABLE II}

Sediment reworking rates $\left(\mathrm{cm} /\right.$ worm per $\left.\mathrm{h} \times 10^{-5}\right)$ calculated from ${ }^{137} \mathrm{Cs}$ burial rates for the first 290 hours and the remainder of experiment 1 and for the first $600 \mathrm{~h}$ and the remainder of experiment 2 .

\begin{tabular}{|c|c|c|c|}
\hline \multicolumn{2}{|c|}{ Sediment conc. } & $\begin{array}{l}24-290 \mathrm{~h} \\
\text { Reworking rate } \\
\left(\mathrm{cm} \text { worm }{ }^{-1} \mathrm{~h}^{-1} \times 10^{-5} \text { ) }\right.\end{array}$ & $\begin{array}{l}290-1032 \mathrm{~h} \\
\text { Reworking rate } \\
\left(\mathrm{cm} \text { worm }^{-1} \mathrm{~h}^{-1} \times 10^{-5}\right)\end{array}$ \\
\hline 42000 & $\mathrm{ng} / \mathrm{g}$ & $0.80(0.11)^{\mathrm{a}}$ & $0.25(0.03)$ \\
\hline 2300 & $\mathrm{ng} / \mathrm{g}$ & $1.83(0.09)$ & $0.62(0.04)$ \\
\hline 218 & $\mathrm{ng} / \mathrm{g}$ & $1.52(0.15)$ & $0.90(0.03)$ \\
\hline 20.6 & $\mathrm{ng} / \mathrm{g}$ & $1.73(0.11)$ & $0.76(0.02)$ \\
\hline Control & & $1.03(0.09)$ & $1.12(0.04)$ \\
\hline \multirow{2}{*}{\multicolumn{2}{|c|}{ Sediment conc. }} & $24-600 \mathrm{~h}$ & $600-1272 \mathrm{~h}$ \\
\hline & & $\begin{array}{l}\text { Reworking rate } \\
\left(\mathrm{cm} / \text { worm per } \mathrm{h} \times 10^{-5}\right)\end{array}$ & $\begin{array}{l}\text { Reworking rate } \\
\left(\mathrm{cm} / \text { worm per } \mathrm{h} \times 10^{-5}\right)\end{array}$ \\
\hline 11500 & $\mathrm{ng} / \mathrm{g}$ & $1.14(0.13)$ & $0.14(0.01)$ \\
\hline 541 & $\mathrm{ng} / \mathrm{g}$ & $1.07(0.06)$ & $0.53(0.03)$ \\
\hline 27 & $\mathrm{ng} / \mathrm{g}$ & $1.42(0.06)$ & $0.80(0.03)$ \\
\hline 3.1 & $\mathrm{ng} / \mathrm{g}$ & $1.64(0.07)$ & $0.79(0.02)$ \\
\hline Control & & $1.39(0.04)$ & $0.86(0.04)$ \\
\hline
\end{tabular}

a Parentheses indicate SE. 
TABLE III

Statistical comparison of reworking rates for the first 290 hours and the remainder of experiment 1 (alpha $<0.05$ ).

\begin{tabular}{|c|c|c|c|c|c|}
\hline $42.0 \mu \mathrm{g} / \mathrm{g}$ & - & & \multicolumn{3}{|c|}{$24-290 \mathrm{~h}$} \\
\hline $2.3 \mu \mathrm{g} / \mathrm{g}$ & n.d. ${ }^{a}$ & - & & & \\
\hline $218^{\mathrm{b}} \mathrm{ng} / \mathrm{g}$ & $\mathrm{F}$ & n.d. & - & & \\
\hline $20.6 \mathrm{ng} / \mathrm{g}$ & $\mathrm{F}$ & n.d. & n.d. & - & \\
\hline \multirow[t]{2}{*}{ Control } & n.d. & $\mathrm{S}$ & $\mathrm{S}$ & $\mathrm{S}$ & - \\
\hline & 42.0 & 2.3 & 218 & 20.6 & Control \\
\hline $42.0 \mu \mathrm{g} / \mathrm{g}$ & - & & \multicolumn{3}{|c|}{$290-1032 \mathrm{~h}$} \\
\hline $2.3 \mu \mathrm{g} / \mathrm{g}$ & $\mathbf{F}$ & - & & & \\
\hline $218 \mathrm{ng} / \mathrm{g}$ & $\mathrm{F}$ & $\mathrm{F}$ & - & & \\
\hline $20.6 \mathrm{ng} / \mathrm{g}$ & F & $\mathrm{F}$ & n.d. & - & \\
\hline \multirow{2}{*}{ Control } & $\mathrm{F}$ & $\mathrm{F}$ & $F$ & F & - \\
\hline & 42.0 & 2.3 & 218 & 20.6 & Control \\
\hline
\end{tabular}

${ }^{a}$ Read from left, then down, $F=$ faster, $S=$ slower, n.d.= no difference.

${ }^{b}$ Example: $218 \mathrm{ng} / \mathrm{g}$ is significantly faster than $42 \mu \mathrm{g} / \mathrm{g}$.

During the first $290 \mathrm{~h}$ of experiment 1 , mean reworking rates from $20.6 \mathrm{ng} / \mathrm{g}, 218$ $\mathrm{ng} / \mathrm{g}$, and $2300 \mathrm{ng} / \mathrm{g}$ microcosms were significantly faster $(P<0.05)$ than those from the highest exposure concentration of $42000 \mathrm{ng} / \mathrm{g}$. The mean control cell rate was not significantly different from the $42000 \mathrm{ng} / \mathrm{g}$ rate (Table III). In the later half of the experiment, all treatment reworking rates slowed relative to the control rate, while the later half control rate was not significantly different from the early control

\section{TABLE IV}

Statistical comparison of reworking rates for the first 600 hours and the remainder of experiment 2 (alpha $<0.05$ ).

\begin{tabular}{clllll}
\hline $11.5 \mu \mathrm{g} / \mathrm{g}$ & - & & & \multicolumn{2}{c}{$24-600 \mathrm{~h}$} \\
$541 \mathrm{ng} / \mathrm{g}$ & n.d. & - & & & \\
$27.0 \mathrm{ng} / \mathrm{g}^{\mathrm{b}}$ & $\mathrm{F}$ & $\mathrm{F}$ & - & & \\
$3.1 \mathrm{ng} / \mathrm{g}$ & $\mathrm{F}$ & $\mathrm{F}$ & $\mathrm{F}$ & - & Control \\
Control & $\mathrm{F}$ & $\mathrm{F}$ & n.d. & $\mathrm{S}$ & \\
& 11.5 & 541 & 27.0 & 3.1 & \\
$11.5 \mu \mathrm{g} / \mathrm{g}$ & - & & & & $600-1272 \mathrm{~h}$ \\
$541 \mathrm{ng} / \mathrm{g}$ & $\mathrm{F}$ & - & & & \\
$27.0 \mathrm{ng} / \mathrm{g}^{\mathrm{b}}$ & $\mathrm{F}$ & $\mathrm{F}$ & - & & \\
$3.1 \mathrm{ng} / \mathrm{g}$ & $\mathrm{F}$ & $\mathrm{F}$ & n.d. & - & \\
Control & $\mathrm{F}$ & $\mathrm{F}$ & n.d. & $\mathrm{F}$ & - \\
& 11.5 & 541 & 27.0 & 3.1 & Control \\
\hline
\end{tabular}

${ }^{a}$ Read from left, then down. $F=$ faster, $S=$ slower, $n . d .=$ no difference.

${ }^{b}$ Example: $27.0 \mathrm{ng} / \mathrm{g}$ is significantly faster than $11.5 \mu \mathrm{g} / \mathrm{g}$. 

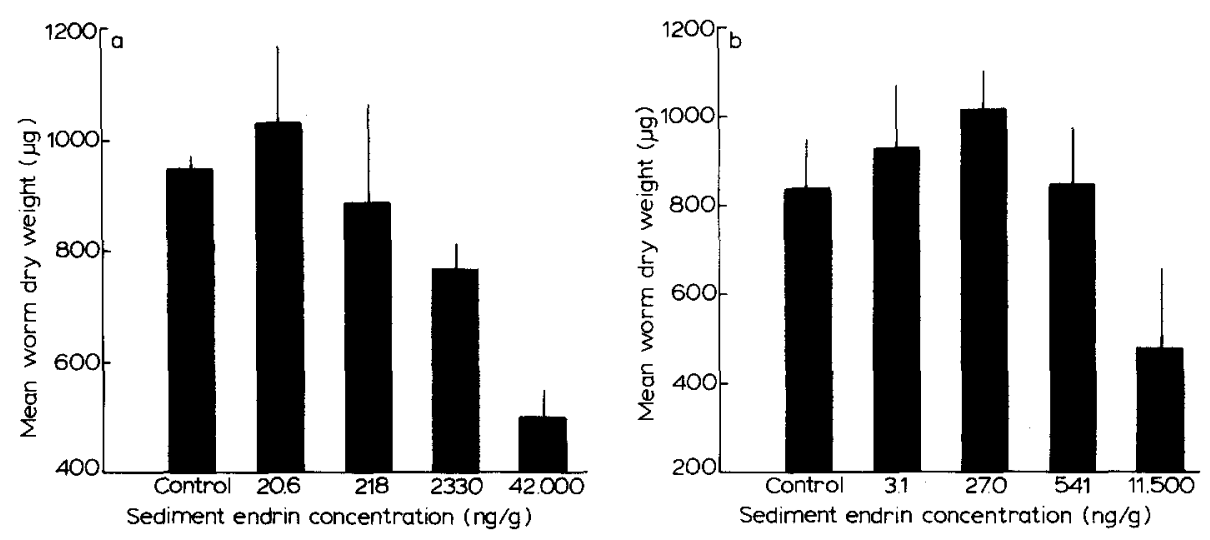

Fig. 2. a,b. Post experimental mean worm dry weights and standard deviations ( $n=6 /$ concentration) as a function of sediment endrin concentration for experiments 1 and 2.

rate. During the first $600 \mathrm{~h}$ of experiment 2 , the mean $27 \mathrm{ng} / \mathrm{g}, 3.1 \mathrm{ng} / \mathrm{g}$, and control rates were faster than the high concentration of $11500 \mathrm{ng} / \mathrm{g}$ and the intermediate concentration of $541 \mathrm{ng} / \mathrm{g}$ (Table IV). Of the two lower concentrations, only the 3.1 $\mathrm{ng} / \mathrm{g}$ rate was significantly faster than the control rate in the first half of the experiment. Unlike the $42000 \mathrm{ng} / \mathrm{g}$ microcosm in experiment 1 , reworking rates in the high concentration of $11500 \mathrm{ng} / \mathrm{g}$ and the intermediate concentration of $541 \mathrm{ng} / \mathrm{g}$ in experiment 2 were significantly slower than the control reworking rate during the first half of the experiment.

At the end of studies, worm dry weights after exposure to high endrin concentrations were reduced relative to control weights. Worms exposed to lower concentrations, however, tended to weigh more than control worms (Fig. 2a,b).

Vertical profiles of porosity in the treatment cells did not differ significantly from control profiles, however, porosity profiles between microcosms with worms and without worms were slightly different.

Vertical endrin distributions in microcosms with reworking activity reflected an apparent upward deposition of the compound relative to 'blanks' (endrin contaminated sediment microcosms without worms; Fig. 3a-d). Organic carbon content (as ashfree dry weight) closely followed the distribution of the compound in the 'blank' microcosms (Fig. 4), consistent with the results of Karickoff and Morris (1985).

The bioaccumulation of endrin by $S$. heringianus was found to range from 34 to 67 times in the five highest experimental sediment concentrations on a dry weight basis. Bioaccumulation factors from the lower concentrations in both experiments were not determined because of detectability problems. There did not appear to be a relationship between sediment concentration and bioaccumulation. 

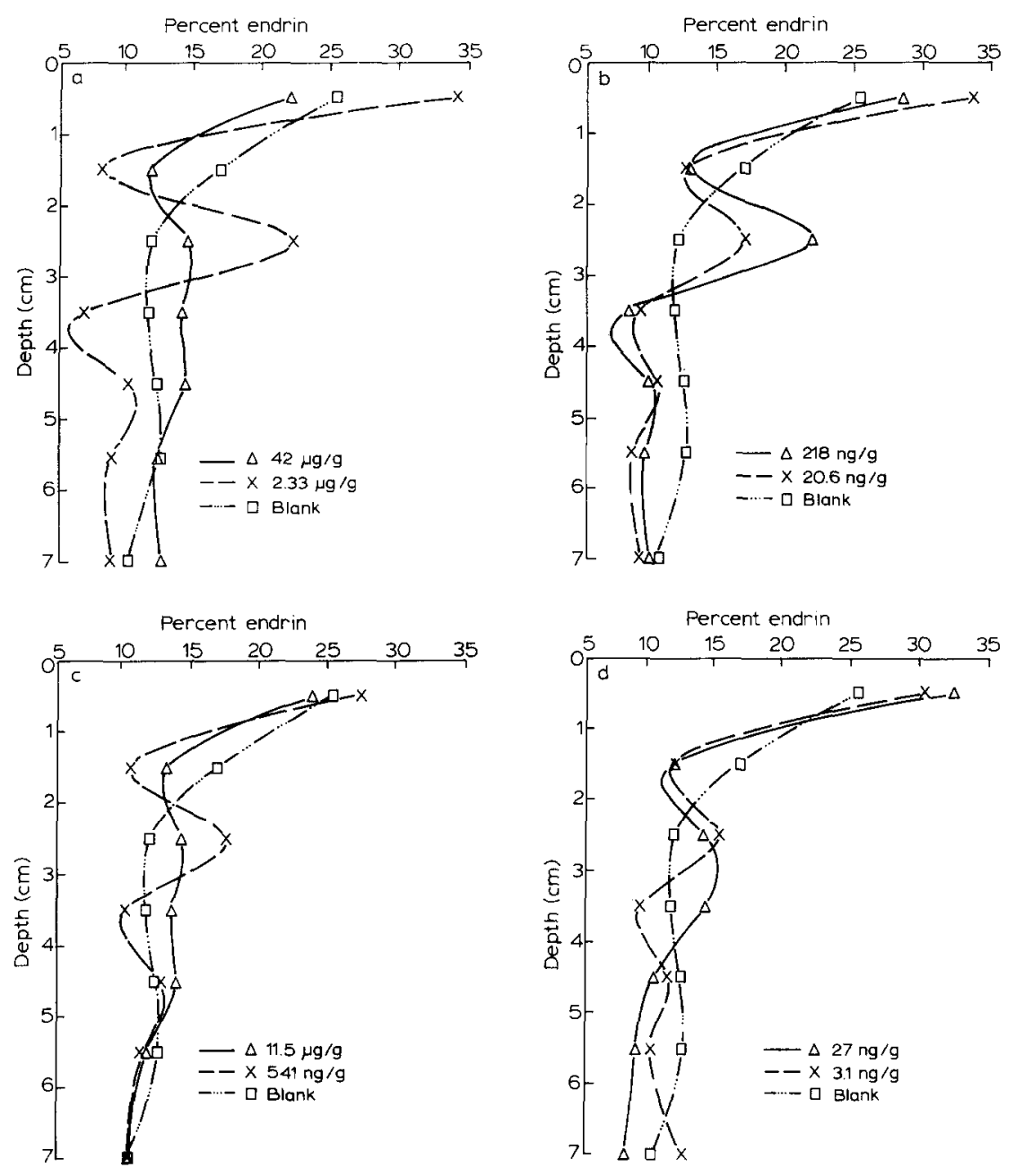

Fig. 3. a-d. Vertical endrin distribution as the percent of the total compound at each centimeter depth interval for microcosm sediments in experiments 1 and 2. Blank distribution reflects endrin position without oligochaete sediment mixing.

\section{DISCUSSION}

Endrin is one of the most toxic pesticides to fish (Grant, 1976). Ninety-six h $\mathrm{LC}_{50}$ values of $1 \mu \mathrm{g} / 1$ or less were found for bluegills, trout, salmon, fathead minnows (Grant, 1976) and flagfish (Hermanutz et al., 1985). Endrin is slightly less toxic to freshwater Crustacea with reported $\mathrm{LC}_{50}$ values of 1.3 to $3.0 \mu \mathrm{g} / 1$ for two species of Gammarus and $320 \mu \mathrm{g} / \mathrm{l}$ for mature crayfish (Sanders, 1972). Although the literature 


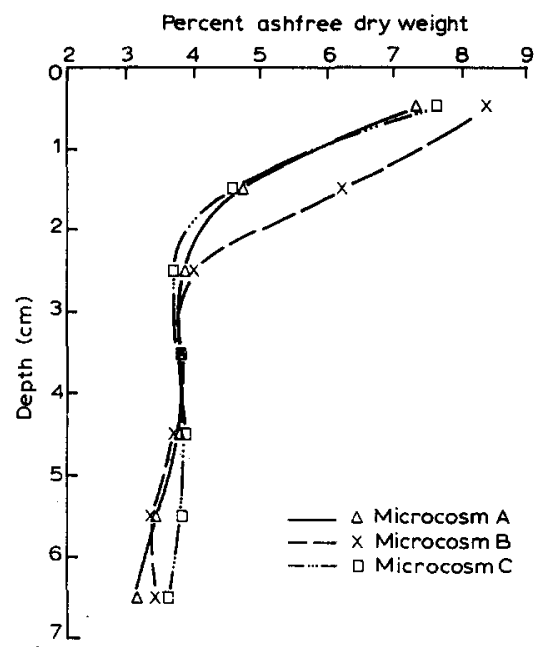

Fig. 4. Percent ashfree dry weights of sediments at $\mathrm{cm}$ depth intervals in 'blank' microcosms.

is sparse relative to other invertebrates, the oligochaetes appear to the be relatively resistant to endrin (Naqvi, 1973) and other pesticides (DDT, chlordane, sevin, malathion, and methoxychlor (Bailey and Lui, 1980)). This resistance is typified in a recent study where $96 \mathrm{~h} \mathrm{LC} 50$ values for $S$. heringianus with endrin averaged $2588 \pm 1974 \mu \mathrm{g} / \mathrm{g}$ dry weight sediment (Keilty et al., 1988).

Studies of oligochaete-sediment-toxicity interactions are rare (Karickoff and Morris, 1985). The tolerance of the tubificid Branchiura sowerbyi was determined for twenty three insecticides, including four chlorinated hydrocarbon pesticides (aldrin, dieldrin, DDT, and endrin) (Naqvi, 1973). No mortality was observed at the high concentration of $4 \mathrm{mg} / \mathrm{l}$ at $21^{\circ} \mathrm{C}$ with the chlorinated compounds, consistent with the high tolerance of other tubificids such as Tubifex sp. and Limnodrilus sp. to DDT (Whitten and Goodnight, 1966). With other pesticides where mortality occurred, significant increases in tolerances were found by adding sediment to the test solutions (Naqvi, 1973). The addition of sediment presumably decreased the bioavailability of the toxicants (Ferguson et al., 1965; Adams et al., 1985; Lynch and Johnson, 1982; for fish, chironomids, and amphipods respectively). A similar response was observed for Tubifex tubifex and Limnodrilus hoffmeisteri exposed to sodium pentachlorophenol (Chapman and Brinkhurst, 1984).

Aside from a reduction in toxicity/bioavailability, the presence of sediment affords a more natural testing environment, particularly when investigating subtle behavioral changes in response to toxicant exposures by infaunal organisms. Unfortunately, very little information is available on the behavioral responses of freshwater oligochaetes to pesticide-contaminated sediment. However, sufficient sediment and/or water concentrations of chlorinated and organophosphate 
pesticides significantly inhibited both the rate and magnitude of marine polychaete burrowing/feeding behavior (Rubinstein, 1979; McLeese et al., 1982; Mohlenberg and Kiorboe, 1983). In these studies worm responses and sediment movements were quantified by either simple observations or time series photographs of sediment surfaces. Although these techniques were suitable for the given experimental designs, neither determine subsurface activities.

Fluorescent glass beads are limited as a tracer of particle movement because they can only be detected close to the microcosm walls, and environmental chambers must be opened to collect data. Opening the test systems is cumbersome and requires 'safelight conditions' to prevent evoking a negative phototropic response from the worms. Use of a gamma scan system avoids these difficulties and affords long term, undisturbed, and highly accurate assessments of sediment burial/oligochaete reworking rates.

By using the gamma scan system, the longterm chronic effects of endrin contaminated sediment on $S$. heringianus reworking rates were measured at concentrations up to five and one half orders of magnitude lower than the $\mathrm{LC}_{50}$. Although the $\mathrm{LC}_{50}$ measurement requires a lower investment of time and resources, it does not permit extrapolation to responses induced by long-term, low level exposures. Measures of reworking patterns require a greater effort, yet more closely mimic a 'real world' exposure, and therefore a 'real world' response.

Reworking rates for the controls were consistent with other oligochaete reworking determinations (reviewed in Fisher et al., 1980 and Krezoski et al., 1984). The exposure to endrin resulted in both the elevation and reduction of reworking rates, dependent on the length of the exposure and the sediment concentration. While changes in reworking for $S$. heringianus also result from variations in the ambient temperature and dissolved oxygen levels (Khlar, 1981; Robbins et al., 1984; White et al., 1987), this is the first demonstration that oligochaete reworking/feeding behavior changes due to a sediment bound toxicant.

Reworking data suggest that the presence of the toxicant at low concentrations stimulates reworking behavior for a considerable length of time, after which reworking decreases. An increased metabolic rate due to the chemical stress may be responsible for the heightened reworking response. Elevated respiration rates of both lumbriculid and tubificid worms occur as a response to aqueous pollutants, such as pulp mill effluent (Whitley, 1968; Whitley and Sakora, 1970; Chapman et al., 1982a, 1982b, 1982c; Brinkhurst et al., 1983). The later half of the exposure shows decreases in reworking rates that are likely due to the accumulated toxic effect. At the high concentration of $42000 \mathrm{ng} / \mathrm{g}$, there was no stimulation in the first half of the experiment, while the reduction in the later portion was most dramatic (Fig. 1a). The decrease in reworking/feeding results in significant reductions in post experimental worm weights from the $42000 \mathrm{ng} / \mathrm{g}$ microcosms. Such responses illustrate the deleterious effects of long-term exposures at concentrations over one and one half orders of magnitude less than the $\mathrm{LC}_{50}$ value. 
Reworking rates and general trends from experiments 1 and 2 were comparable. However, in the second experiment, only the $3.1 \mathrm{ng} / \mathrm{g}$ cells exhibited significantly faster reworking than the control early in the experiment. At the intermediate and high concentrations, the reworking rates were slower than the controls early on, suggesting a more toxic response than from the higher concentration of $42000 \mathrm{ng} / \mathrm{g}$ in experiment 1 . Differences in sensitivity of the worms between the experiments may be attributed to the use of worms from different collections. For ideal replication and comparison, both experiments should have been run simultaneously, with worms from one Lake Michigan sampling. Equipment and space constraints made this impossible. Although the reworking rate from $27 \mathrm{ng} / \mathrm{g}$ was not significantly different from the control rate in experiment 2, the control reworking rate did exceed all other treatment rates in the later portion of the experiment, and the high concentration $(11.5 \mu \mathrm{g} / \mathrm{g})$ once again showed the most dramatic reduction in reworking.

Changes in reworking rates somewhat paralleled post experimental worm dry weights and sediment endrin loads. In the first experiment, weights were much lower in worms exposed to the high concentrations relative to controls, whereas worms exposed to low concentrations were similar to, and greater than controls (Fig. 2a). The observed changes in body weights probably resulted from the altered feeding patterns manifested in the altered reworking patterns. A similar, yet less distinct trend was observed in experiment 2 (Fig. 2b). Again, worms exposed to the high concentration of $11500 \mathrm{ng} / \mathrm{g}$ had a diminished reworking rate and a greatly reduced worm weight, while those exposed to low concentrations had similar and elevated weights relative to the control weights. Changes in body weights did not correspond to microcosm sediment concentrations as well as they did in experiment 1. Data at the high concentrations from both experiments do, however, clearly indicate the value of post contaminant exposure body weight measurements. Although they are 'endpoint' measures, they reflect the integrated physiological response to long term contaminant exposure and provide support for the reworking data.

Post experimental vertical endrin profiles suggest upward worm mediated movement of the compound (Fig. 3a-d). A similar response was observed using tubificid worms and hexachlorobenzene, pentachlorobenzene, and trifluralin (Karickoff and Morris, 1985). Transport of endrin by S. heringianus appears to depend on the concentration in the sediment. At the highest concentration in experiment $1(42000$ $\mathrm{ng} / \mathrm{g}$ ), the endrin distribution was very similar to the 'blank' distribution (Fig. 3a) presumably because the worms did little feeding/reworking. At a concentration of $2300 \mathrm{ng} / \mathrm{g}$ (Fig. 3a) and lower (Fig. 3b), significantly higher reworking activities occurred along with significant upward endrin transport. In each case, the upwardly transported compound was preceded by a marked decrease in the centimeter fraction beneath it. In the $2-3 \mathrm{~cm}$ interval another small peak was usually present, consistent with the current oligochaete feeding model which predicts characteristic waves (Robbins, 1986). Similar responses were observed in experiment 2 (Fig. 3c,d). In the $11500 \mathrm{ng} / \mathrm{g}$ microcosm, the endrin distribution was very similar to the 
'blank', consistent with the $42000 \mathrm{ng} / \mathrm{g}$ cell in experiment 1 . The vertical endrin distribution in the $541 \mathrm{ng} / \mathrm{g}$ cell more closely resembles the distributions at lower concentrations (Fig. 3d) with slightly less compound in the surface fraction. Thus, upward transport of a sediment bound toxicant corresponds to significant oligochaete sediment reworking. The worms tend to selectively ingest compounds with high partition coefficients that are associated with the finer, organic fractions (McCall and Tevesz, 1982). This selectivity is the result of the size limitation of the worm's prostomium and of the higher food quality due to the rich bacterial flora found on the organic component (Brinkhurst and Chua, 1969; Wavre and Brinkhurst, 1971; Brinkhurst et al., 1972; Chua and Brinkhurst, 1973; Brinkhurst and Austin, 1979). The organic carbon vertical profiles (as ashfree dry weight, Fig. 4) of the 'blanks' closely followed the endrin distributions in the 'blanks' corroborating this notion. A relationship between organic carbon and highly sorbed toxicants was also observed by Karickoff and Morris (1985).

Porosity can be influenced by oligochaete sediment mixing, particularly in sandy sediments, where surface water content increases as a result of tubificid feeding (Tevesz et al., 1980). Worms selectively remove the subsurface finer grained particles and transport them to the surface (McCall and Tevesz, 1982). However, in very fine grained sediments, tubificid oligochaetes did not influence the surface water content of Lake Erie muds apparently due to compaction (McCall and Fisher, 1980). Porosity profiles from microcosms with worms in our experiments differed slightly from the vertical porosity profile of the 'blank'. Microcosms without worms generally had a slightly higher porosity in the $0-1$ and $1-2 \mathrm{~cm}$ fractions than both experimental and control microcosms with worms. The 'blank' also continued to decrease in porosity with depth after $2 \mathrm{~cm}$, while the others did not. These differences were probably a result of further compaction of the sediments by the conveyor-belt feeding worms. It is possible that a 10 day settling of microcosm sediments prior to the addition of worms may be too short. There were, however, no measurable differences between the control cell and the experimental cells in both experiments, suggesting that the toxicity of the compound was not manifested in this measurement. Additionally, porosity did not relate to the vertical distribution of endrin.

Bioaccumulation of endrin by $S$. heringianus was significant, ranging from 34-67 times the concentration of the sediment. Concentration factors by the tubificids, Limnodrilus hoffmeisteri and Tubifex tubifex, of pp'DDE, Mirex, and PCB in spiked samples from Lake Ontario were approximately five times lower than our observed values (Oliver, 1987). Considering the use of different species, sediments, compounds, experimental designs, etc., the determinations are reasonably similar and suggest that aquatic oligochaetes may sequester substantial quantities of persistent pollutants.

Based on this study and previous research with endrin (Keilty et al., 1988), expected oligochaete responses at various concentrations juxtaposed with the types of 


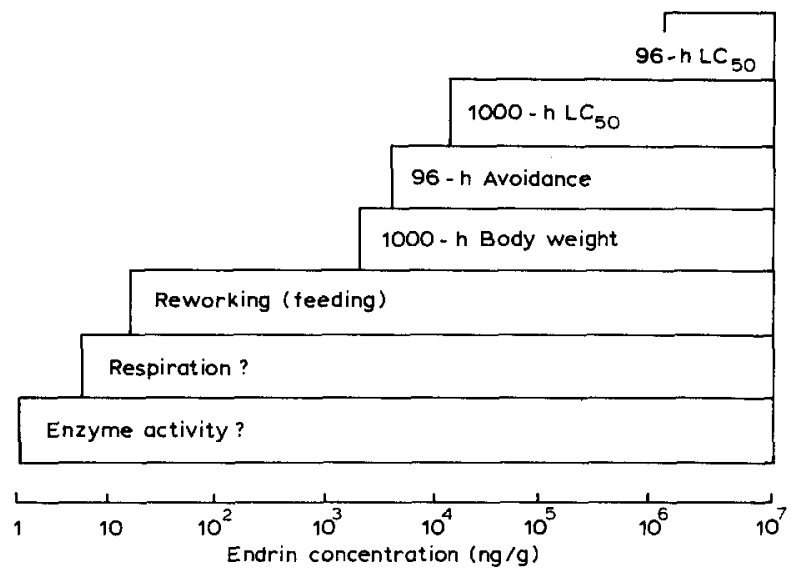

Fig. 5. Summary of measured and hypothesized responses by Stylodrilus heringianus to endrin-laden sediments in various assays. Values are estimations placed along a presumed continuum of response.

assays employed can be summarized to provide perspective between the assay types and the sensitivity of the responses (Fig. 5). A 96-h $\mathrm{LC}_{50}$ requires the highest sediment concentration. An approximate $1000-\mathrm{h} \mathrm{LC}_{50}$, a 96 - $\mathrm{h}$ sediment avoidance $\mathrm{EC}_{50}$ (Keilty et al., 1988), and 50\% body weight losses after approximately 1000 -h exposures, are all about equally sensitive at 1-2 orders of magnitude lower sediment concentration compared to the $96-\mathrm{h} \mathrm{LC}_{50}$. The significant chronic reduction in reworking rate occurs at about 5 orders of magnitude below the $96-\mathrm{h} \mathrm{LC}_{50}$ and at levels that have been observed in Great Lakes sediments. Because the reworking rate is an integrated physiological response, even more sensitive endpoints such as changes in respiration or enzyme activity may be found. However, the reworking rate is the most sensitive oligochaete bioassay for sediment associated toxicants to date and because it is an integrated physiological response, all aspects of bioavailability, organism compensatory mechanisms and organism function are incorporated in the response.

\section{CONCLUSION}

Reworking rates of $S$. heringianus measured with a gamma scan system were significantly altered by the presence of a sediment bound toxicant in concentrations up to 5.5 orders of magnitude lower than the $96-\mathrm{h} \mathrm{LC}_{50}$ value. At low concentrations, reworking data suggested possible stimulatory effects during the first $300-600$ $h$, after which there were significant reductions relative to control rates. At high concentrations, rates were equal to or lower than control rates in the first 300-600 $\mathrm{h}$, followed by a definite reduction relative to control rates. 
Post experimental worm dry weights tended to be inversely related to high endrin sediment concentrations, presumably reflecting decreased feeding and/or increased stress associated with the higher sediment endrin loads.

Relatively high post experimental surficial endrin concentrations demonstrated worm mediated upward toxicant transport in microcosms with actively feeding worms. Transport did not occur in microcosms where reworking was significantly retarded.

Bioconcentration of endrin by $S$. heringianus was significant, ranging from 34 to 67 times the sediment concentrations.

The importance of sublethal (and even lethal) testing of freshwater oligochaetes in sediments has been neglected. Sublethal impairment of an animal's development or its capacity to live and compete in its environment can greatly reduce the chances of survival for both the individual, and in extreme cases, the entire species (Anderson and d'Apollonia, 1982). Because oligochaetes are one of the most important components of the infaunal macrobenthos of lacustrine systems, the need exists to examine the effects of low level chronic toxicant exposure to these organisms and their role in the fate and persistence of xenobiotics.

\section{ACKNOWLEDGEMENTS}

The authors gratefully acknowledge John Robbins for his critical review of an earlier draft of the manuscript and help with the gamma scan system. Eugene Stoermer, William Benninghoff, Brian Eadie, and Wayne Gardner are also thanked for review of the manuscript. The help of the crew of the $R / V$ Shenahon in organism, mud, and water collection was invaluable. Funding for this study was provided in part by a grant from the Great Lakes Environmental Research Laboratory under the National Oceanic and Atmospheric Administration's Cooperative Agreement NA81-RA-H-00003. This work is contribution no. 594 from The Great Lakes Environmental Research Laboratory, Ann Arbor, Michigan, and contribution no. 493 from the Great Lakes Research Division, University of Michigan, Ann Arbor, Michigan.

\section{REFERENCES}

Adams, W.J., R.A. Kimerle and R.G. Mosher, 1985. Aquatic safety assessment of chemicals sorbed to sediments. Aquatic toxicology and hazard assessment: Seventh Symposium, ASTM STP 854, edited by R.D. Cardwell, R. Purdy and R.C. Bahner, American Society for Testing and Materials, Philadelphia, pp. 429-453.

Aller, R.C., 1978. Experimental studies of changes produced by deposit feeders on pore water, sediment, and overlying water chemistry. Am. J. Sci. 278, 1185-1234.

Aller, R.C., 1980. Relationships of tube-dwelling benthos with sediment and overlying water chemistry. In: Marine benthic dynamics, edited by K.R. Tenore and B.C. Coull, University of South Carolina Press, Columbia, pp. 285-308. 
Aller, R.C., 1982. The effects of macrobenthos on chemical properties of marine sediment and overlying water. In: Animal-sediment relations, the biogenic alteration of sediments, edited by P.L. McCall and M.J.S. Tevesz, Plenum, New York, pp. 53-102.

Anderson, P.O. and S. d'Apollonia. 1982. Aquatic Animals. In: Principles of ecotoxicology edited by G.C. Butler, J. Wiley and Son, New York, pp. 187-221.

Bailey, H.C. and D.H.W. Lui, 1980. Lumbriculus variegatus, a benthic oligochaete, as a bioassay organism. Aquatic toxicology, ASTM STP 707, edited by J.C. Eaton, P.R. Parrish and A.C. Hendricks, American Society for Testing and Materials, pp. 205-215.

Baumfalk, Y.A., 1979. Heterogeneous grain size distribution in tidal flat sediment caused by bioturbation activity of Arenicola marina (Polychaeta). Neth. J. Sea Res. 13, 428-440.

Biggar, J.W. and K.E. Chua, 1969. Preliminary investigations of the exploitation of some potential nutritional resources by three sympatric tubifid oligochaetes. J. Fish. Res. B. Can. 26, 2659-2668.

Brinkhurst, R.O. and M.J. Austin, 1979. Assimilation of aquatic oligochaetes. Int. Rev. Ges. Hydrobiol. 63, 863-863.

Brinkhurst, R.O., P.M. Chapman and M.A. Farrell, 1983. A comparative study of respiration rates of some aquatic oligochaetes in relation to sublethal stress. Int. Rev. Ges. Hydrobiol. 68, 683-699.

Brinkhurst, R.O., K.E. Chua and N.K. Kaushik, 1972. Interspecific interactions and selective feeding by tubificid oligochaetes. Limnol. Oceanogr. 17, 122-133.

Cadee, G.C., 1979. Sediment reworking by the polychaete Heteromastus filiformis on a tidal flat in the Dutch Wadden Sea. Neth. J. Sea Res. 13, 441-456.

Chapman, P.M. and R.O. Brinkhurst, 1984. Lethal and sublethal tolerances of aquatic oligochaetes with reference to their use as a biotic index of pollution. Hydrobiologia 115, 139-144.

Chapman, P.M., M.A. Farrell and R.O. Brinkhurst, 1982a. Effects of species interactions on the survival and respiration of Limnodrilus hoffmeisteri and Tubifex tubifex (Oligochaeta, Tubificidae) exposed to various pollutants and environmental factors. Water Res. 16, 1405-1408.

Chapman, P.M., M.A. Farrell and R.O. Brinkhurst, 1982b. Relative tolerances of selected aquatic oligochaetes to individual pollutants and environmental factors. Aquat. Toxicol. 2, 47-67.

Chapman, P.M., M.A. Farrell and R.O. Brinkhurst, 1982c. Relative tolerances of selected aquatic oligochaetes to combinations of pollutants and environmental factors. Aquat. Toxicol. 2, 69-78.

Chua, K.E. and R.O. Brinkhurst, 1973. Evidence of interspecific interactions in the respiration of tubificid oligochaetes. J. Fish. Res. B. Can. 30, 617-622.

Davis, R.B., 1974a. Stratigraphic effects of tubificids in profundal lake sediments. Limnol. Oceanogr. $19,468-488$.

Davis, R.B., 1974b. Tubificids alter profiles of redox potential and $\mathrm{pH}$ in profundal lake sediment. Limnol. Oceanogr. 19, 342-345.

Davis, R.B., D.C. Thurlow and F.E. Brewster, 1975. Effects of burrowing tubificid worms on the exchange of $P$ between lake sediments and overlying water. Verh. Int. Ver. Limnol. 19, 382-394.

Edgington, D.N. and J.A. Robbins, 1976. Patterns of deposition of natural and fallout radionuclides in the sediments of Lake Michigan and their relation to limnological processes. In: Environmental geochemistry, edited by J.O. Nriagu, Ann Arbor Science Publishers, Ann Arbor, Michigan, pp. 705-709.

Ferguson, D.E., J.L. Ludge, J.P. Wood and J.W. Prather, 1965. The effect of mud on the bioactivity of pesticides on fish. J. Miss. Acad. Sci. 11, 219-228.

Fisher, J.B., 1982. Effects of macrobenthos on the chemical diagenesis of freshwater sediments. In: Animal-sediment relations, the biogenic alteration of sediments, edited by P.L. McCall, M.J.S. Tevesz, Plenum, New York, pp. 177-218.

Fisher, J.B., W.J. Lick, P.L. McCall and J.A. Robbins, 1980. Vertical mixing of lake sediments by tubificid oligochaetes. J. Geophys. Res. 85, 3997-4006.

Grant, B.F., 1976. Endrin toxicity and distribution in freshwater: areview. Bull. Environ. Contam. Toxicol. 15, 283-289. 
Hermanutz, R.O., J.G. Eaton and L.H. Mueller, 1985. Toxicity of endrin and malathion mixtures to flagfish (Jordanella floridae). Arch. Environ. Contam. Toxicol. 14, 307-314.

Karickoff, S.W. and K.R. Morris, 1985. Impact of tubificid oligochaetes on pollutant transport in bottom sediments. Environ. Sci. Technol. 19, 51-56.

Keilty, T.J., D.S. White and P.F. Landrum, 1988. Short term lethality and sediment avoidance assays with endrin contaminated sediment and two oligochaetes from Lake Michigan: Stylodrilus heringianus (Lumbriculidae) and Limnodrilus hoffmeisteri (Tubificidae). Arch. Environ. Contam. Toxicol. 17, 95-101.

Kikuchi, E. and Y. Kurihara, 1977. In-vitro studies on the effects of tubificids on the biological, chemical and physical characteristics of submerged rice-field solid and overlying water. Oikos 29, 348-356.

Klahr, P.C., 1981. The effects of temperature and density on the rate of sediment reworking by Stylodrilus heringianus, M.S. Thesis. Univ. of Michigan, Ann Arbor, Michigan, pp. 82.

Krezoski, J.R., 1976. Macrobenthos and mixing processes in Lake Huron sediments. M.S. Thesis, Univ. of Michigan, Ann Arbor, Michigan, 34 pp.

Krezoski, J.R., 1981. The influence of zoobenthos on fine-grained particle reworking and benthic solute transport in Great Lakes sediments. Ph.D. dissertation, Univ. of Michigan, Ann Arbor, Michigan, 104 pp.

Krezoski, J.R. and J.A. Robbins, 1985. The vertical distribution of feeding and particle selective transport of $137 \mathrm{Cs}$ in lake sediments in lumbriculid oligochaetes. J. Geophys. Res. 90, 11999-12006.

Krezoski, J.R., S.C. Mozley and J.A. Robbins, 1978. Influence of benthic macroinvertebrates on mixing profundal sediments in southeastern Lake Huron. Limnol. Oceanogr. 23, 1011-1016.

Krezoski, J.R., J.A. Robbins and D.S. White, 1984. Dual radiotracer measurement of zoobenthos mediated solute and particle transport in freshwater. J. Geophys. Res. 89, 7939-7947.

Lynch, T.R. and H.E. Johnson, 1982. Availability of a hexachlorobiphenyl isomer to benthic amphipods from experimentally contaminated natural sediments. In: Aquatic toxicology and hazard assessment: Fifth Conference, ASTM STP 766, edited by J.G. Pearson, R.B. Foster and W.E. Bishop, American Society for Testing and Materials, pp. 273-287.

Matisoff, G., J.B. Fisher and S. Matis, 1985. Effects of benthic macroinvertebrates on the exchange of solutes between sediments and freshwater. Hydrobiologia 122, 19-33.

McCall, P.L. and J.B. Fisher, 1980. Effects of tubificid oligochaetes on physical and chemical properties of Lake Erie sediments. In: Aquatic oligochaete biology, edited by R.O. Brinkhurst and D.G. Cook, Plenum, New York, pp. 253-318.

McCall, P.L. and M.J.S. Tevesz, 1982. The effects of benthos on physical properties of freshwater sediments. In: Animal-sediment relations, the biogenic alteration of sediments, edited by P.L. McCall and M.J.S. Tevesz, Plenum, New York, pp. 105-176.

McLeese, D.W., L.E. Burridge and J. Van Dinter, 1982. Toxicities of five organochlorine compounds in water and sediment to Nereis virens. Bull. Environ. Contam. Toxicol. 28, 21-220.

Mohlenberg, F. and T. Kiorboe, 1983. Burrowing and avoidance behavior in marine organisms exposed to pesticide-contaminated sediment. Mar. Pollut. Bull. 14, 57-60.

Naqvi, S.M.Z., 1973. Toxicities of twenty-three insecticides to a tubificid worm Branchiura sowerbyi from the Mississippi delta. J. Econ. Ent. 66, 70-74.

Neely, W.B., D.R. Branson and G.E. Blau, 1974. Partition coefficient to measure bioconcentration potential of organic chemicals in fish. Environ. Sci. Technol. 8, 1113-1115.

Oliver, B.G., 1987. Biouptake of chlorinated hydrocarbons from laboratory-spiked and field sediments by oligochaete worms. Environ. Sci. Technol. 21, 785-790.

Patil, K.C., F. Matsumura and G.M. Boush, 1970. Degradation of endrin, aldrin, and DDT by soil microorganisms. Appl. Microbiol. 19, 879-881.

Pesticide Analytical Manual, 1979. U.S. Dept. Health, Education and Welfare. Food and Drug Administration, Washington, D.C. 
Petr, T., 1977. Bioturbation and exchange of chemicals in the mud-water interface. In: Interactions between sediments and freshwater, edited by H.L. Gotterman. Junk Publ., The Hague, pp. 216-225.

Rhoads, D.C., 1974. Organism/sediment relations on the muddy sea floor. Oceanogr. Mar. Biol. Rev. $12,263-300$.

Rippey, B. and D.H. Jewson, 1982. The rates of sediment-water exchange of oxygen and sediment bioturbation in Lough Neagh, Northern Ireland. Hydrobiologia 92, 377-382.

Robbins, J.A., 1982. Stratigraphic and dynamic effects of sediment reworking by Great lakes zoobenthos. Hydrobiologia 92, 611-622.

Robbins, J.A., 1986. A model for particle-selective transport of tracers in sediments with conveyor-belt deposit feeders. J. Geophys. Res. 91, 8542-8558.

Robbins, J.A. and D.N. Edgington, 1975. Determination of recent sedimentation rates in Lake Michigan using $\mathrm{Pb}-210$ and Cs-137. Geochim. Cosmochim. Acta. 39, 285-304.

Robbins, J.A., K. Husby-Coupeland and D.S. White, 1984. Precise radiotracer measurements of the rate of sediment reworking by Stylodrilus heringianus: Effects of variable dissolved oxygen levels. J. Great Lakes Res. 4, 335-347.

Robbins, J.A., T.J. Keilty, D.S. White and D.N. Edgington, 1988. Correlations between tubificid abundances and sediment composition and accumulation rates in Lake Erie. Can. J. Fish. Aquat. Sci. (in press).

Robbins, J.A., J.R. Krezoski and S.C. Mozley, 1977. Radioactivity in sediments of the Great lakes: Post-depositional redistribution by deposit-feeding organisms. Earth Planet. Sci. Lett. 36, 325-333.

Robbins, J.A, P.L. McCall, J.B. Fisher and J.R. Krezoski, 1979. Effect of deposit feeders on migration of cesium-137 in lake sediments. Earth Planet. Sci. Lett. 42, 277-287.

Rubinstein, N.I., 1979. A benthic bioassay using time-lapse photography to measure the effect of toxicants on the feeding behavior of lugworms (Polychaeta:Arenicolidae). In: Marine pollution: functional responses, edited by W.B. Vernberg, A. Calabrese, F.P. Thurberg, F.J. Vernburg, Academic Press, New York, pp. 341-351.

Sanders, H.O., 1972. Toxicity of some insecticides to four species of malacostracan crustaceans. Bur. Sport Fish Wildl. Tech. Paper No. 66, 19 pp.

Sharom, M.S., J.R.W. Miles, C.R. Harris and F.L. McEwen, 1980. Behavior of 12 insecticides in soil and aqueous suspensions of soil and sediment. Water Res. 14, 1095-1100.

Tevesz, M.J.S., F.M. Soster and P.L. McCall, 1980. The effect of size-selective feeding by-oligochaetes on the physical properties of river sediments. J. Sediment. Petrol. 50, 561-578.

Wavre, M., and R.O. Brinkhurst, 1971. Interactions between some tubificid oligochaetes and bacteria found in the sediments of Toronto Harbour, Ontario. J. Fish. Res. B. Can. 28, 335-341.

Weil, L., G. Dure and K.L. Quentin, 1974. Solubility in water of insecticide chlorinated hydrocarbons and polychlorinated biphenyls in view of water pollution. Z. Wasser Abwasser Forsch. 7, 169-175.

White, D.S., P.C. Klahr and J.A. Robbins, 1987. Effects of temperature and density on sediment reworking by Stylodrilus heringianus (Oligochaeta: Lumbriculidae). J. Great Lakes Res. 13, 147-156.

Whitley, L.S., 1968. The resistance of tubificid worms to three common pollutants. Hydrobiologia 32, 193-205.

Whitley, L.S. and R.A. Sakora, 1970. The effect of three common pollutants on the respiration rate of tubificid worms. J. Wat. Pollut. Control Fed. 42, R57-R66.

Whitten, B.K. and C.J. Goodnight, 1966. Toxicity of some common insecticides to tubificids. J. Water Pollut. Control Fed. 38, 227-235. 